\title{
Determination of the Appropriate Ratio of Rice Bran to Cassava Leaf Meal Mixture as an Inoculum of Rhizopus Oligosporus in Broiler Chicken Ration
}

\author{
Annisa ${ }^{1}$, Yose Rizal ${ }^{2 *}$, Mirnawati $^{2}$, Irfan Suliansyah ${ }^{3}$ and Amri Bakhtiar ${ }^{4}$ \\ ${ }^{1}$ PhD Student at Graduate Program, Universitas Andalas, Padang, Indonesia, 25163 \\ ${ }^{2}$ Lecturer at Faculty of Animal Science, Universitas Andalas, Padang, Indonesia, 25163 \\ ${ }^{3}$ Lecturer at Faculty of Agriculture, Universitas Andalas, Padang, Indonesia, 25163 \\ ${ }^{4}$ Lecturer at Faculty of Pharmacy, Universitas Andalas, Padang, Indonesia, 25163 \\ *Corresponding author’s Email: yrizal@ansci.unand.ac.id; ORCID: 0000-0003-3010-126x
}

\begin{abstract}
Rice bran (RB) was used as a medium for the fermentation process because it contained complete nutrients necessary for the growth of microbes. The ability to induce a fermentation substrate by microbes dependent on the availability of an inducer in the medium. The enzyme activity would increase when a suitable inducer was in the medium. In order to increase protease and cellulase activities of Rhizopus oligosporus in processing Cassava Leaf Meal (CLM), it was necessary to add CLM in medium producing an inoculum Rhizopus oligosporus. This study was conducted in a completely randomized design with 4 treatments and 5 replications. The treatments were ratios of RB to CLM as follows: 100:0\% (A), 90:10\% (B), 80:20\% (C), and 70:30\% (D). The observed variables were protease activity, cellulase activity, dry matter content, organic matter content and the total colony of Rhizopus oligosporus numerically. The different ratios of RB to CLM significantly affected protease and cellulase activities as well as the content of dry matter and organic matter. The addition of 10\% CLM to the RB medium increased protease and cellulase activities and reduced dry matter and organic matter contents. However, when more than 10\% CLM was added, it reduced the protease and cellulase activities and increased dry matter and organic matter content. The highest total colony of Rhizopus oligosporus was numerically in treatment B (90:10\% of RB to CLM ratio). The appropriate ratio of RB to CLM mixture as the inoculum of Rhizopus oligosporus, based on their enzyme activities, dry matter, and organic matter contents, and the total colony was 90:10\% (treatment B).
\end{abstract}

Received: 17 Dec. 2019

Accepted: 01 Feb. 2020

Key words: Cassava leaf meal, Enzyme activity, Inoculum, Rhizopus oligosporus, Rice bran.

\section{INTRODUCTION}

Cassava leaf flour (CLM) has the potential to be used as an alternative feed ingredient. Judging from its availability, CLM is quite widely available. Cassava leaf flour is obtained as waste material when harvesting cassava roots from cassava plants. Cassava production in West Sumatra reaches 201,833 tons, in Indonesia 19,341,233 tons (Statistics of Indonesia, 2018).This cassava plant was cultivated on an area of 792,952 Hectare (Ha) or 0.8 million Ha (Statistics of Indonesia, 2018). The production of fresh cassava leaves per Ha was between 7 to 15 tons by Sudaryanto et al., 1982 in Yuniza et al., (2016). From the area of cassava plantation and cassava leaf production per hectare, the availability of fresh cassava leaves as animal feed was plentiful, ranging from
5.6 to 12 million tons or about 1 to 2 million tons under dry conditions per year. If only 1 million tons of dried cassava leaves was used as chicken feed, this amount could be estimated to feed up to 274 million laying hens per year when the cassava leaves were included $8 \%$ in the ration.

The potential of CLM as an alternative feed ingredient in terms of nutritional content. The nutritional content of CLM is as follows: dry matter (DM) $25.30 \%$, crude protein (CP) $25.1 \%$, crude fiber (CF) $11.4 \%$, crude fat $12.7 \%$, nitrogen retention $46,1 \%$ and $9.1 \%$ ash (Iheukwumere et al., 2008). On the other hand, CLM has a limiting factor as alternative feed ingredients. The use of CLM in broiler chicken rations can only be used up to 5\% because utilization of up to 10 and $15 \%$ can reduce the efficiency of feed use (Wyllie and Chamanga, 1979; 
Melesse et al. 2018). The use of CLM in broiler chicken rations is still limited due to high $\mathrm{CF}$, tannins, $\mathrm{HCN}$, alkalis, low digestibility (Ravindran et al., 1986) and deficiency of amino acids containing sulfur, especially methionine (Eggum, 1970). Therefore, the use of CLM was still limited. In order to further increase the amount of CLM in poultry rations, the physical, chemical and biological fermentation must be carried out.

The biological fermentation by using microbes is a process of the activity of microorganisms or microbes that can produce the product whose texture, flavor, smell and nutrient quality change better than that of the raw material (Mirnawati et al., 2019a; Mirnawati et al., 2019b; Dewi et al., 2019; Mirnawati et al., 2018; Mirrnawati et al., 2017; Adrizal et al., 2017; Mirnawati et al., 2013; Rizal et al., 2013; Rizal et al., 2012; Mirnawati et al., 2012; Aisjah and Abun, 2012; and Mirnawati et al., 2010). According to Sugiharto (2019), solid-fermentation using fungi could be a simple method to improve the nutrient qualities of cassava pulp and thus increased the production of such a cheap agro-industrial by-product in chicken rations. According to Han et al. (2003), Rhizopus oligosporus produced protease, lipase, alpha-amylase, glutaminase, and alpha-galactosidase and (Dewi, 2015) found that Rhizopus oligosporus also produces cellulase. The presence of these enzymes were expected to reduce the anti-nutrients and toxins contained in CLM and also increase their nutritional values (Sumiati et al., 2011), thus increasing the use of CLM in broiler chicken rations.

To increase the productivity of Rhizopus oligosporus in producing hydrolytic enzymes (protease and cellulase) and to increase the enzyme activities, it was necessary to produce Rhizopus oligosporus starter or inoculum from Rice Bran (RB) and CLM mixture as an inducer. Therefore, the ability of hydrolytic enzymes for the degradation of CP and CF of CLM supposed to increase. The addition of CLM to the inoculum as an inducer should accelerate the adaptation phase and increase the productivity of Rhizopus oligosporus hydrolytic enzymes. Rhizopus oligosporus would be able to synthesize the necessary enzymes required for metabolism according to the availability of inducer in the starter (Kurnia, 2010; Purkan et al., 2016). The addition of CLM as a substrate in the production of Rhizopus oligosporus inoculums could accelerate the adaptation phase (Soeprijanto et al., 2008 and Zakaria et al., 2013).

Therefore, the purpose of this study was to investigate the appropriate ratio of RB to CLM mixture that will be utilized for producing inoculum of Rhizopus oligosporus.

\section{MATERIALS AND METHODS}

\section{Experimental design}

This experiment was conducted in a complete randomized design with 4 treatments and 5 replications. The treatments were the combination ratio of RB to CLM including 100:0\% (A), 90:10\% (B), 80:20\% (C), and 70:30\% (D). These combinations of RB and CLM mixtures were fermented by using Rhizopus oligosporus at the dose of one test tube for 100 gram (g) dry matter and 2-day fermentation length.

\section{Measured variables}

These measured variables wereprotease and cellulase activities as well as dry matter and organic matter contents, and the numericalcalculation ofthe total colony of Rhizopus oligosporus in each treatment.

\section{Data analysis}

All the data were analyzed by analysis of variance of complete randomized design. The differences among treatment means were detected by Duncan's Multiple Range Test or (DMRT) according to Steel and Torrie (1980).

\section{Preparation of Cassava Leaf Meal sample}

After harvesting the tuber roots, cassava leaves were taken from two-third of the entire leaves from the an teriorside. Cassava leaves were dried under the sun and then milled in a two mm screen.

\section{Propagation of fungi}

Eight $\mathrm{g}$ of Potato Dextrose Agar or (PDA) was weighed and placed into the glass cup and added with 200 milliliter ( $\mathrm{ml}$ ) of distilled water and heated on the hotplate with constant stirring until it was limpid. This PDA solution was poured into 30 test tubes (each test tube contained $5 \mathrm{ml}$ solution) and covered with cotton and aluminum foil, then sterilized by using an autoclave at 2 atmosphere (atm.) pressure and $121^{\circ} \mathrm{C}$ for 15 minutes. Other inoculation pieces of equipment (one needle, one mask, one glove) were also sterilized. They were chilled in laminar flow while UV light was turned on a tilted position until solid. Rhizopus oligosporus was inoculated by using sterile needle against tilted PDA medium in a sterile environment. Then, the inoculated PDA medium was sealed in test tubes with cotton and aluminum foil and incubated for 36 hours in an incubation container in flowing air under facultative anaerobic condition. 
The starters were weighted according to the treatments [ratios of RB to CLM were 100:0\% (A), 90:10\% (B), 80:20\% (C) and 70:30\% (D)]. To each starter was added $65 \mathrm{ml}$ of water (until the moisture content was $45 \%$ ) and homogenized, and then these starters and minerals were prepared according to Brook et al. (1969). The composition of nutrients included Urea $7.5 \mathrm{~g}, \mathrm{MgSO} 4$ $7 \mathrm{H} 2 \mathrm{O} 0.375 \mathrm{~g}, \mathrm{FeSO} 47 \mathrm{H} 2 \mathrm{O} 0.15 \mathrm{mg}$, ZnSO $47 \mathrm{H} 2 \mathrm{O}$ $0.15 \mathrm{mg}$, MnSO $44 \mathrm{H} 2 \mathrm{O} 0.15 \mathrm{mg}$, KH2PO $1.5 \mathrm{~g}$, and thiamine hydrochloride $18.75 \mathrm{mg}$, which had dissolved in $100 \mathrm{ml}$ equates. The mixture was used, $5 \mathrm{ml}$ in $100 \mathrm{~g}$ subtract were sterilized using autoclave at $2 \mathrm{~atm}$. pressure, temperature $121^{\circ} \mathrm{c}$ for 15 minutes, and chilled in laminar flow. Rhizopus oligosporus in the PDA medium was inoculated in laminar flow into each starter and then was incubated in facultative anaerobe over a period of 36 hours.

\section{Determination of Enzyme Activity Crude enzyme extract}

$10 \mathrm{~g}$ of inoculum sample was weighed and then immersed in $90 \mathrm{ml}$ of $0.05 \mathrm{M}$ phosphate buffer at $\mathrm{pH} 7$ in $250 \mathrm{ml}$ of Erlenmeyer and inserted into the incubator shaker for 2 hours at $27^{\circ} \mathrm{C}$ at 100 round per minute (rpm). Afterwards, the solution was filtered and the filtrate was taken out, and then was centrifuged at a speed of $5000 \mathrm{rpm}$ for 15 minutes, thus the supernatant was taken out as a crude enzyme extract for the purposes of analyzing enzyme activity by the following methods.

\section{Protease activity}

One percent casein solution was pipette up to $2.5 \mathrm{ml}$ and phosphate buffer $(0.1 \mathrm{M} \mathrm{pH} \mathrm{7)}$ was pipetted up to 1.5 $\mathrm{ml}$ and then placed into a test tube and then mixed by using a vortex, then was incubated in a water bath at $37^{\circ} \mathrm{C}$ for 10 minutes. One $\mathrm{ml}$ of crude enzyme extract was added and then incubated for 10 minutes in a water bath at $50{ }^{\circ} \mathrm{C}$. To obtain the blank, enzyme activity was stopped by adding $5 \mathrm{ml}$ of $20 \%$ TCA solution, then mixed by using a vortex and then refrigerated for 30 minutes to agglomerate the protein. On the other hand, the sample was centrifuged at $5000 \mathrm{rpm}$ for 15 minutes at $4^{0} \mathrm{C}$, then filtered and the supernatant was taken. Furthermore, two $\mathrm{ml}$ of supernatant was pipetted into the test tube and $0.5 \mathrm{ml}$ of $\mathrm{NaOH}$ up to 5 $\mathrm{ml}$ and folinciocalteu reagent was added to $0.5 \mathrm{ml}$ and then allowed to stand for 10 minutes. Furthermore, the absorbance was measured using a spectrophotometer at a wavelength of $650 \mathrm{~nm}$. According to Henriette (1993), the calculation is done with the following equation;

Activity of protease enzyme $(\mathrm{U} / \mathrm{ml})=(\mathrm{Y} \times \mathrm{a}) / \mathrm{b} \times 1 / \mathrm{t}$
$\mathrm{Y}=$ Absorbance of sample

$a=$ the a value of the regression curve $Y: a+b x$

$b=$ value $b$ of the regression curve $Y: a+b x$

$\mathrm{t}=$ incubation time

Casein regression curve $=\mathrm{y}=0.031 \mathrm{x}+1.136 \mathrm{R}^{2}=$ 0.986

\section{Cellulase activity}

One $\mathrm{ml}$ crude enzyme extract was pipetted and added one $\mathrm{ml}(0.5 \mathrm{ml} \mathrm{CMC}+10 \mathrm{ml}$ phosphate buffer $)$ and then poured into the microtube, and incubated for 30 minutes at $40^{\circ} \mathrm{C}$ in a water bath shaker. Then one $\mathrm{ml}$ of this mixture solution was taken out and poured into the test tube, and then one $\mathrm{ml}$ of Nelson AB (25 ml Nelson A and one $\mathrm{ml}$ Nelson B)was added. Nelson A was consisted of $2.5 \mathrm{~g}$ of $\mathrm{Na} 2 \mathrm{CO} 3,2 \mathrm{~g}$ of $\mathrm{NaHCO} 3,2 \mathrm{~g}$ of $\mathrm{NaSO} 4,2.5 \mathrm{~g}$ of $\mathrm{KNaCaH} 4 \mathrm{O} 6.4 \mathrm{H} 2 \mathrm{O}$ and $100 \mathrm{ml}$ of distilled water. Nelson $\mathrm{B}$ was consisted of $75 \mathrm{~g}$ of $\mathrm{COSO} 4$ and one drop of $\mathrm{H} 2 \mathrm{SO} 4$. Thus, the mixture was heated in boiling water for 20 minutes, and after the solution got cold, one $\mathrm{ml}$ of phosphor-molybdate and seven $\mathrm{ml}$ of distilled water were added. The absorbance was measured by using a spectrophotometer Simadzu 1800 from Kyoto, Japan at a wavelength of $575 \mathrm{~nm}$ (Nelson, 1994). The calculation is done with the following equation;

$$
\begin{aligned}
& \text { Cellulase activity }(\mathrm{U} / \mathrm{ml})=(\mathrm{X} \times \mathrm{P} \times 1000) /(\mathrm{T} \times \mathrm{M}) \\
& \mathrm{X}=\text { the result of standard curve conversion } \\
& \mathrm{P}=\text { Dilution } \\
& \mathrm{T}=\text { Time } \\
& \mathrm{BM}=\text { Molecular weight of glucose } \\
& \text { Glucose standard curve }=\mathrm{y}=0.045 \mathrm{x}-0.010 \mathrm{R}^{2}=
\end{aligned}
$$
0.994

\section{Calculation of Total Colonies}

The total colonies were calculated by the Pour Plate Method (Putri and Kurnia, 2018). The counting of the colonies had tube sterile from the beginning to the end. All equipments were moistened with $70 \%$ alcohol. In addition, the process was carried out near a flame to reduce or prevent microbial contaminants to the equipment and media. The calculation of whole colony was startedwith the productionof physiological solutions. In the first step, oneg of sample was mixed with nine $\mathrm{ml}$ of distilled water, then it was homogenized. One $\mathrm{ml}$ of this solution was taken with a micropipette and added to nine $\mathrm{ml}$ of distilled water to obtain a 1:10 dilution. The solution of 1:10 homogenized dilutions was taken as much as one $\mathrm{ml}$ and then poured into a test tube with nine $\mathrm{ml}$ of distilled water to made a 2:10 dilution, and the same procedure was used 
to prepare the solution until 10:10 dilutions. In the next process, media plate count agar was made using Potato Dextrose Agar (PDA) solution. The PDA solution was sterilized together with Petri dishes and other equipment by using an autoclave at a pressure of 2 atm., $121{ }^{0} \mathrm{C}$ for 15 minutes. Then, $0.1 \mathrm{ml}$ of the physiological solution from the dilution tube (10-6) was pipetted into a sterile Petri dish, after which the PDA solution was poured under warm conditions. It was also placed on a flat table and gently shaken like the number eight. This procedure was also repeated for physiological solutions resulting from dilutions of 10-8 and 10-10. All planted Petri dishes were labeled and sealed with stretch film. All Petri dishes were incubated for 24 hours in an incubator jar. After the incubation, the fungi colonies were observed and counted using a colony counter. Total colonies were calculated according to Standard Plate Count (SPC). Several colonies that had been assembled from a large collection of colonies counted as one colony, and a row or chain of colonies considered as a combined row were also counted as a colony. The amount per gram colony was determined using the equation according to Sukmawati and Hardianti (2018).

$$
\mathrm{N}=\mathrm{n} \times \frac{1}{\mathrm{fP}}
$$

$\mathrm{N}=$ total colony per gram of sample (CFU/g);

$\mathrm{n}=$ Number of colonies counted in the colony counter

$f \mathrm{P}=$ Dilution factor of the sample (initial dilution $\times$ amount of colonies grown)

\section{RESULT}

The effect of RB and CLM ratios in the production of Rhizopus oligosporus inoculum on their protease and cellulase activities, total colony, and dry matter and organic matter contents were shown in table 1 . The effect of ratios and $\mathrm{RB}$ to CLM for producing inoculum of Rhizopus oligosporus on protease activity was statistically significant $(\mathrm{p}<0.05)$. The highest protease activity was found in treatment $\mathrm{B}(9.84 \mathrm{U} / \mathrm{ml})$, in which it was not different from treatment $\mathrm{C}(9.90 \mathrm{U} / \mathrm{ml})$, and treatment $\mathrm{D}$ $(9.79 \mathrm{U} / \mathrm{ml})$ but it was different from treatment A $(9.13$ $\mathrm{U} / \mathrm{ml})$

The effect of the ratio of RB and CLM to produce the inoculum Rhizopus oligosporus on cellulase activity was statistically significant $(\mathrm{p}<0.05)$ (table 1$)$. The highest activity of cellulase was at treatment $\mathrm{B}(1.50$ $\mathrm{U} / \mathrm{ml})$. It was not different compared to treatment $\mathrm{C}(1.51$ $\mathrm{U} / \mathrm{ml}), \mathrm{D}(1.52 \mathrm{U} / \mathrm{ml})$, but it was different from treatment A $(1.38 \mathrm{U} / \mathrm{ml})$. The ratio of RB to CLM for assembling the inoculum of Rhizopus oligosporus significantly affected the dry matter content $(\mathrm{p}<0.05)$. The lowest dry matter content was found in treatment B (91.63\%). It was different from treatments A $(92.67 \%), \mathrm{C}(92.59 \%)$ and D $(92.94 \%)$. Meanwhile, treatments A, C, and D were not different. The effect of the ratio of RB and CLM to produce an inoculum of Rhizopus oligosporus on the content organic matter was statistically significant $(\mathrm{p}<$ 0.05). The lowest organic matter content was found in treatment B (76.48\%), but it was not different compared to treatment $\mathrm{C}(77.66 \%)$. Whereas, this treatment was different from treatments A (78.55) and D (79.00\%).

Table 1. The effects of the ratios of Rice bran and Cassava leaf meal for producing Rhizopus oligosporus starter, on their protease and cellulase activities, and the content of dry matter, organic matter, and the numerical form of total colony, in the Non-Ruminant Nutrition Laboratory, at the Faculty of Animal Science, Andalas University, Padang, Indonesia.

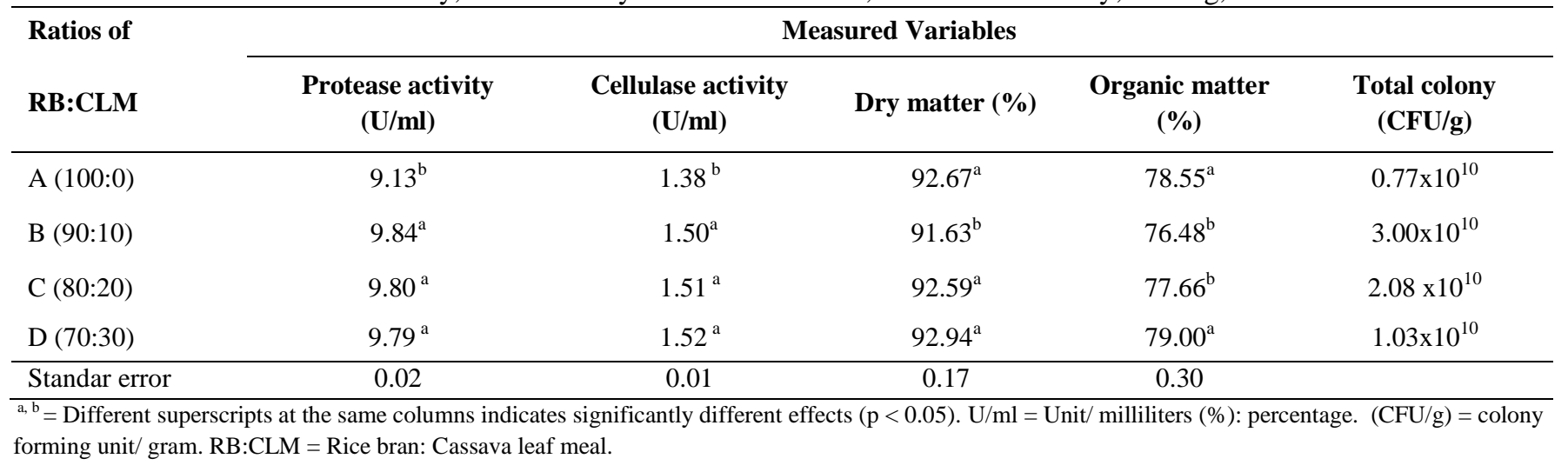




\section{DISCUSSION}

\section{The activity of protease}

The highest protease activity was founded by the addition of cassava leaves as a source of protein up to $10 \%$. Although increasing the addition of cassava leaves up to $20 \%$ and $30 \%$ did not significantly alter the activity of the protease, it decreased numerically since the addition of $10 \%$ inducer reached optimal. Thus, if the addition of the inducer was increased, it did not increase the protease activity, but reduced it. The protease activity increased to an optimal level according to the inducer contained in the substrate in the starter. According to Kurnia (2010), the protease activity increased to optimal level depending on the inducer contained in the substrate in the starter.

The mechanism of increasing protease activity in accordance with the available inducer to the optimal point was that cassava leaves would bind to the repressor protein as an available inducer so that the repressor protein underwent allosteric changes that could change its shape and cause the repressor to cease the ability to bind to the operator. As a result, the RNA polymerase could copy the genes required for cassava leaf degradation so that the Rhizopus oligosporus could synthesize the enzymes necessary to degrade the available inducers. In this case, cassava leaves were used as a source of protein because the abundant crude protein content was $21.59 \%$.

The table 1 indicated that the increase in the addition of cassava leaves (inducer) was directly proportional to the high production of the enzyme protease. This stage lasted until the optimal inducer concentration, which was the addition of $10 \%$ of cassava leaves with an enzyme activity of $9.84(\mathrm{U} / \mathrm{ml})$. The addition of $20 \%$ and $30 \%$ of cassava leaves did not significantly increase the protease activity, but instead decreased it numerically since the addition of cassava leaves as an inducer had exceeded the optimal concentration. This excessive inducer concentration caused saturation of the protease enzyme productivity, thus inhibited the formation of enzyme complexes on the substrate (Purkan et al., 2016).

\section{The cellulase activity}

Cellulase activity increased to the optimum at the time of addition of $10 \%$ cassava leaves as an inducer, then there was no significant increase on addition of $20 \%$ and $30 \%$ of cassava leaves. This happened because at the point of addition of $10 \%$ of cassava leaves had reached the optimal point of adding inducers, increasing the addition of inducers (cassava leaves) did not increase enzymatic productivity. According to Kurnia (2010), the activity of cellulase enzymes increased to the optimum point according to the inducers available in the substrate in the starter. The mechanism of increasing cellulase activity by adding an inducer of cassava leaves to the optimal point was that cassava leaves as an inducer will bind the repressor protein so that the repressor protein undergoes allosteric changes which can change its shape and cause the repressor can no longer bind to the operator. As a result, the RNA polymerase could copy the genes needed for cassava leaf degradation so that the Rhizopus oligosporus could synthesize the enzymes needed for metabolism. In this case, cassava leaves are used as fiber inducers because of the high CF content of $14.59 \%$.

In the table, it can be seen that the increase in the concentration of the inducer is directly proportional to the high activity of cellulase. This lasted until the optimum point of adding $10 \%$ inducer (cassava leaves) with enzyme activity $(1.50 \mathrm{U} / \mathrm{mL})$, then at an increase of $20 \%$ and $30 \%$, there was no significant increase in cellulase activity. This happens because, the addition of an inducer of more than $10 \%$ causes saturation in the productivity of cellulase enzymes, because the concentration of the inducer is too large to inhibit the formation of enzyme complexes on the substrate, so that enzyme production does not run optimally (Purkan et al., 2016).

\section{Dry matter content}

The low dry matter content at treatment B was due to the high protease activity in this treatment, in which it hydrolyzed the protein of the substrate. Thus, the dry matter content of the substrate was reduced. The decrease in dry matter after fermentation was an indicator of the success of fermentation, as the retaining of dry matter in the fermentation process was affected by the use of nutrients from the substrate (dry matter) by microbes as a source of carbon, nitrogen and minerals, and the release of $\mathrm{CO} 2$ and energy in the form of heat that evaporated with water particles. According to Astuti et al. (2017), the fermentation process could result in a reduction in the amount of dry matter. The water molecule was formed through a catabolic process that remodeled complex compounds into simpler materials

\section{Organic matter content}

The high and low content of organic matter in the treatment was caused by microbial activity in the fermentation process, which caused the breakdown of the substrate content, whereby microorganisms could easily 
digest organic matter. The fermentation of organic substances in the form of glucose, alcohol, and amino acids led to changes that affecting the nutritional value. According to Astuti et al. (2017), the fermentation process carried out by microorganisms, so that the carbohydrates were converted into alcohol, organic acids, water, and $\mathrm{CO}_{2}$. The use of tofu waste in addition to nitrogen sources was also a source of carbohydrates for microbes used in the fermentation, which causes an increase in water content and leaded to the loss of organic matter.

\section{Total colony}

The total colonies of Rhizopus oligosporus in treatment $\mathrm{A}\left(0.77 \times 10^{10} \mathrm{CFU} / \mathrm{g}\right), \mathrm{B}\left(3.00 \times 10^{10} \mathrm{CFU} / \mathrm{g}\right), \mathrm{C}$ $\left(2.08 \times 10^{10} \mathrm{CFU} / \mathrm{g}\right)$, and $\mathrm{D}\left(1.03 \times 10^{10} \mathrm{CFU} / \mathrm{g}\right)$ differ numerically. The highest total of Rhizopus oligosporus colonies in treatment B was due to the availability of inducers needed to synthesize enzymes by Rhizopus oligosporus, so that the entire colony became stable and continued to grow (Kurnia, 2010). Conversely, too much inducer concentration inhibited the formation of substrate enzyme complexes, so that enzyme production was not optimal. It also disrupted the stability and growth of the colony (Purkan et al., 2016).

\section{CONCLUSION}

The best ratio of rice bran and cassava leaf meal for producing the inoculum of Rhizopus oligosporus, based on the enzyme activities, the dry matter and the content of organic matter, and the whole colony was $90 \%$ rice bran and $10 \%$ cassava leaves (B treatment).

\section{DECLARATIONS}

\section{Acknowledgment}

This research was funded by the Ministry of Research Technology and Higher Education of the Republic of Indonesia under the PMDSU program. We are very grateful to the Ministry of Research Technology and Higher Education of the Republic of Indonesia and Rector of the Andalas University for their supports in this program.

\section{Author's contribution}

Annisa, Yose Rizal, Mirnawati, Irfan Suliansyah and Amri Bakhtiar participated in design, experimental procedure, writing, revised, and reviewing the final edition of manuscript.

\section{Competing interests}

The authors have declared that no competing interest exists.

\section{Consent to publish}

The authors guarantee that this work has not been published elsewhere and any person named as a coauthor of this study is aware of the facts and has agreed to be named.

\section{REFERENCES}

Adrizal, Heryandi Y, Amizar R and Mahata ME (2017). Evaluation of pineapple [Ananas comosus (L.) Merr] waste fermented using different local microorganism solutions as poultry feed. Pakistan Journal Nutrition, 16: 84-89. DOI: http://10.3923/pjn.2017.84.89

Aisjah T (2012). Bioprocess of winged bean seeds (psophocarpus tetragonolobus (1) dc) by Rhizopus oligosporus to improve of pure protein content and decreased of cyanide. Journal of Animal Science (Jurnal Ilmu Ternak) Universitas Padjadjaran12(1): 35-40. DOI: https://doi.org/10.24198/jit.v12i1.5135

Astuti T, Rofiq MN and Nurhaita N (2017). Evaluation of the content of dry matter, organic matter and crude protein of palm fronds fermentation with the addition of carbohydrate sources. Journal of Animal Husbandry (Journal Peternakan), 14 (2): 42-47. DOI: https://org/10.24014/jupet.v14i2.4247

Brook EJ, Stantion WR and Bridge AW (1969). Fermentation methods for protein enrichment of cassava. Biotechnology and Bioengineering 11: 1271-1284. DOI: https://doi.org/10.1002/bit.260110620

Dewi S (2015). Isolation and identification of cellulolytic thermophilic fungi and examination of its cellulase enzyme activity. Thesis. Faculty of Agricultural Technology. Gadjah Mada University. Yogyakarta. Google Scholar, Available at: http://etd.repository.ugm.ac.id/index.php?mod=penelitian_detail\&s $\mathrm{ub}=$ PenelitianDetail\&act=view\&typ=html\&buku_id=87475\&obyek _id=4

Dewi YL, Yuniza A, Nuraini, Sayuti K and Mahata ME (2019). Fermentation of Sargassum binderi Seaweed for Lowering Alginate Content of Feed in Laying Hens. Journal of World's Poultry Research. 9(3): 147-153 DOI: https://dx.doi.org/10.36380/jwpr.2019.18

Han BZ, Ma Y, Rombouts FM and Nout MR (2003). Effects of temperature and relative humidity on growth and enzyme production by action mucorelegans and Rhizopus oligosporus during sufupehtze preparation. Food Chemistry.. 81 (1): 27-34. DOI: https://doi.org/10.1016/S0308-8146(02)00347-3

Henriette C, Zinebi S, Aumaitre MF, Petitdemange E and Petitdemange $H$ (1993). Protease and lipase production by a strain of Setaria marcessen. Journal of Industrial Microbiology, 12(2): 129-135. DOI: https://doi.org/10.1007/BF01569913

Iheukwumere FC, Ndubuisi EC and Mazi EA (2008). Performance, Nutrient utilization and organ characteristics of broilers fed cassava leaf meal (Manihot esculenta Crantz). Pakistan Journal of Nutrition, 7 (13): 13-16. DOI: https://10.3923/pjn.2008.13.16

Kurnia DR (2010). Study of lipase enzyme activity from Aspergillus niger as a biocatalyst in the glycerolysis process to produce monoacylglycerol (Studi aktivitas enzim lipase dari Aspergillus niger sebagai biokatalis dalam proses gliserolisis untuk menghasilkan monoasilgliserol). Doctoral dissertation, Universitas Diponegoro, Semarang. Available at: http://eprints.undip.ac.id/36573/

Melesse A, Masebo M and Abebe A (2018). The substitution effect of noug seed (Guizotia abyssinica) cake with cassava leaf (Manihot 
Escutulata Crantz.) meal on feed intake, growth performance, and carcass traits in broiler chickens. Journal of Animal Husbandry and Dairy Science, 2(2): 1-9. Available at: https://www.sryahwapublications.com/journal-of-animalhusbandry-and-dairy-science/pdf/v2-i2/1.pdf

Mirnawati, Ciptaan G and Ferawati (2017). The effect of Mananolytic fungi and humic acid dosage to improve the nutrient content and quality of fermented palm kernel cake. International journal of Chemistry Technology Research, 10(2): 56-61. Available at: http://www.sphinxsai.com/2017/ch_vol10_no2/1/(5661)V10N2CT.pdf

Mirnawati, Ciptaan G and Ferawati (2019a). Improving the quality and nutrient content of palm kernel cake through fermentation with Bacillus subtilis. International Journal of Animal and Veterinary Sciences, 31(7). Available at: http://www.lrrd.org/lrrd31/7/mirna31098.html

Mirnawati, Ciptaan G and Ferawati (2019b). The Effect of Bacillus subtilis Inoculum Doses and Fermentation Time on Enzyme Activity of Fermented Palm Kernel Cake. Journal of World's $\begin{array}{llll}\text { Poultry Research 9(4): 211-216. } & \text { DOI: }\end{array}$ https://dx.doi.org/10.36380/jwpr.2019.26

Mirnawati, Djulardi A and Ciptaan G (2018). Utilization of fermented palm kernel cake with Sclerotium rolfsii in broiler ration. International Journal of Poultry Science. 17(7): 342-347. DOI: http://10.3923/ijps.2018.342.347

Mirnawati, Djulardi A and Marlida Y (2013). Improving the quality of palm kernel cake fermented by Eupenicillium javanicum as poultry ration. Pakistan Journal of Nutrition, 12 (12): 1085-1088. DOI: http://10.3923/pjn.2013.1085.1088.

Mirnawati, Kompiang IP and Latif SA (2012). Effect of substrate composition and inoculums dosage to improve quality of palm kernel cake fermented by Aspergillus niger. Pakistan Journal of Nutrition, 11(5): 434-438. DOI: http://10.3923/pjn. 2012. 434.438.

Mirnawati RY, Marlida Y and Kompiang IP (2010). The role of humic acid in palm kernel cake fermented by Aspergillus niger for poultry ration. Pakistan Journal of Nutrition, 9 (2): 182-185. DOI: http://10.3923/pjn.2010.182.185

Nelson N (1994). A. Photometric Adaption of Somogyi Method for Determination of Glucose. The Journal of Biological Chemistry, ., 153-375. Available at: http://www.jbc.org

Pooja NS and Padmaja G (2014). Pretreatment techniques to enhance the enzymatic degradability of agricultural and processing residues of cassava. Journal of Microbiology and Biotechnology Research, 4(1): 57-67. Available at: http://scholarsresearchlibrary.com/JM

Priadi DO, Permana DR, Dona SE, Hartati S and Sudarmonowati EN (2009). Selection of Indonesia cassava (Maniho tesculenta Crantz) genotype as source of $\beta$-carotene. Journal of Biological Diversity, 10 (1): 6-11. DOI: https://10.13057/biodiv/d100102

Purkan P, Baktir A and Sayyidah AR (2016). Produksi Enzim Kitinase dari Aspergillus Niger Menggunakan Limbah Cangkang Rajungan sebagai Induser (Production of Chitinase Enzymes from Aspergillus niger using rajungan shell as waste inducer). Journal Kimia Riset, 1 (1): 34-41. DOI: https://org/10.20473/jkr.vli1.2440

Putri AM and Kurnia P (2018). Identification of coliform bacteria and total microbes in dung-dung ice around Muhammadiyah University,
Surakarta campus. Indonesian Nutrition Media (Media Gizi Indonesia), 12: 41-48. DOI: 10.20473/mgi.vl3il.41-48

Ravindran V, Kornegay ET, Rajaguru ASB, Potter LM and Cherry JA (1986). Cassava leaf meal as a replacement for coconut oil meal in broiler diets. Poultry Science, 65: 1720-1727. DOI: https://org/10.3382/ps.0651720

Rizal Y, Nuraini, Mirnawati and Mahata ME (2013). Comparisons of nutrients contents and nutritional values of palm kernel cake fermented by using different fungi. Pakistan Journal of Nutrition, 12 (10): 943-948. DOI: https://10.3923/pjn.2013.943.948.

Rizal Y, Mahata ME, Joli I and Wu G (2012). Improving the nutrient quality of juice wastes mixture through fermentation by using Trichoderma viridae for poultry diet. Pakistan Journal of Nutrition, 11 (3): 203-207. DOI: 3923/pjn.2012.203-207

Soeprijanto, Ratnaningsih T and Prasetyaningrum (2008). Bioconversion of cellulose from corn cob waste to glucose using Aspergillus niger mushroom . Purification Journal (Jurnal Purifikasi), 9(2):105-114. DOI: https://doi.org/10.12962/j25983806.v9.i2.146; Available at: https://purifikasi.id/index.php/purifikasi/article/view/146

Statistics Indonesia (BPS - Badan Pusat Statistik) (2018). Available at: https://www.bps.go.id/

Steel RGD and Torrie JH (1980). Principle and Procedures Statistics: A Biometrical Approach. 2nd Edn., McGraw Hill Book Co., New York. Available https://www.scirp.org/(S(i43dyn45teexjx455qlt3d2q))/reference/Re ferencesPapers.aspx?ReferenceID=383208 Google Scholar

Sugiharto S (2019). A review on fungal fermented cassava pulp of as a cheap alternative feedstuff in poultry ration. Journal of World's Poultry Research, 9(1): 01-06. DOI: https://dx.doi.org/10.36380/jwpr.2019.0

Sukmawati and Hardianti F (2018). Analysis of Microbial Total Plate Count (TPC) in Snapper Salted Fish in Sorong City, West Papua. Jurnal Biodjati, 3(1):72-78. Available at: http://journal.uinsgd.ac.id/indx.php/biodjati

Sumiati, Farhanuddin, Hermana W, Sudarman A, Istichomah N and Setiyono A (2011). Broiler chicken performance given jatropha seed meal rations (Jatrophacurcas l.) Fermented using Rhizopus oligosporus. Animal Husbandry Media, 34 (2): 117-125. DOI or Available at: DOI: https://doi.org/10.5398/medpet.2011.34.2.117. Google Scholar

Wyllie D and Chamanga PJ (1979). Cassava Leaf Meals in Broiler Diets. Tropical Animal Production. 4(3): 232-240. Available at: http://www.fao.org/WAICENT/FaoInfo/Agricult/aga/AGAP/FRG/ TAP43/4_3_4.PDF

Yuniza A, Nova TD, Angga WA, Annisa and Rizal Y (2016). Effects of the combinations of cassava leaf meal and palm kernel cake mixture fermented by Bacillus amyloliquefaciens on the alteration of their dry matter, crude protein, crude fiber, and crude lipid contents. Pakistan Journal of Nutrition, 15:1049-1054. DOI: https://10.3923/pjn.2016.1049.1054

Zakaria Y, Novita CI and Samadi S (2013). The effectiveness of fermentation with different substrate sources on the quality of rice straw. Jurnal Agripet, 13(1): 22-25. DOI: https://doi.org/10.17969/agripet.v13i1.548 